\title{
PEMODELAN JUMLAH KUNJUNGAN WISATAWAN MANCANEGARA KE INDONESIA MELAUI BANDARA NGURAH RAI BALI DENGAN MODEL SARIMA-ARCH
}

\author{
NURUL AISHAH, DODI DEVIANTO, MAIYASTRI \\ Program Studi S1 Matematika, \\ Fakultas Matematika dan Ilmu Pengetahuan Alam, Universitas Andalas, \\ Kampus UNAND Limau Manis Padang, Indonesia. \\ email : nurul1999.aisyah@gmail.com,ddevianto@sci.unand.ac.id,maiyastri@sci.unand.ac.id
}

Diterima 12 Juni 2021 Direvisi 22 Juni 2021 Dipublikasikan 26 Juli 2021

\begin{abstract}
Abstrak. Suatu data deret waktu dipengaruhi oleh beberapa faktor, seperti faktor trend dan faktor musiman. Data deret waktu yang dipengaruhi oleh trend dan musiman dapat dimodelkan dengan model SARIMA. Namun, model SARIMA tidak selalu menghasilkan ragam sisaan yang konstan pada data musiman yang berfluktuasi tinggi atau model yang diperoleh dipengaruhi oleh efek heteroskedastisitas. Salah satu model yang dapat mengatasi efek heteroskedastisitas adalah model ARCH/GARCH. Oleh karena itu, digunakan model ARCH/GARCH untuk mengatasi heteroskedastisitas pada data musiman . Penelitian dilakukan menggunakan data musiman yang juga memiliki fluktuasi tinggi, yaitu data jumlah kunjungan wisatawan mancanegara ke Indonesia melalui bandara Ngurah Rai Bali pada bulan Januari 2008 sampai Desember 2019. Model terbaik yang diperoleh untuk data tersebut adalah $\operatorname{SARIMA}(0,1,1)(0,1,1)_{12} \mathrm{ARCH}(1)$.
\end{abstract}

Kata Kunci: SARIMA, ARCH, GARCH

\section{Pendahuluan}

Indonesia adalah salah satu negara yang memiliki keindahan alam yang sangat beragam. Keindahan alam tersebut dapat menarik perhatian wisatawan, baik wisatawan yang berasal dari Indonesia (wisatawan domestik) maupun wisatawan yang berasal dari luar Indonesia (wisatawan mancanegara).

Banyaknya kunjungan wisatawan mancanegara ke Indonesia dapat diketahui dengan melihat hasil pencatatan yang dilakukan oleh Badan Pusat Statistik (BPS). Salah satu informasi yang diperoleh dari pencatatan kunjungan wisatawan mancanegara pada website BPS adalah data bulanan banyaknya kunjungan wisatawan mancanegara ke Indonesia melalui beberapa pintu masuk, yaitu pintu udara, pintu laut, dan pintu darat.

Data yang diperoleh dari pengamatan suatu objek dalam selang waktu atau periode tertentu dikatakan sebagai data deret waktu [3]. Oleh karena itu, data

*penulis korespondensi 
harian, data mingguan, data bulanan, maupun data tahunan dari jumlah kunjungan wisatawan mancanegara juga termasuk data deret waktu. Setiap pembahasan yang berkaitan dengan data deret waktu, seperti trend, kestasioneran data, pembentukan model terbaik, dan penanganan efek ragam sisaan data juga dapat diterapkan untuk data kunjungan wisatawan mancanegara [1].

Data deret waktu yang telah stasioner dalam rata-rata dan ragam dimodelkan dengan model deret waktu seperti Autoregressive (AR), Moving Average (MA) atau ARMA yang merupakan gabungan dari proses AR dan MA. Namun, untuk data deret waktu yang fluktuatif, asumsi kestasioneran tidak selalu terpenuhi. Ada tiga jenis ketidakstasioneran, yaitu tidak stasioner terhadap rata-rata, tidak stasioner terhadap ragam dan tidak stasioner terhadap rata-rata dan ragam [3], dan dimodelkan dengan model Autoregressive Integrated Moving Average (ARIMA). Untuk data musiman atau data yang dipengaruhi oleh musim dimodelkan menggunakan model Seasonal ARIMA atau disingkat SARIMA [3].

Selain itu, ada asumsi yang harus dipenuhi oleh model deret waktu, salah satunya adalah model tersebut memiliki ragam sisaan yang konstan atau asumsi homoskedastisitas. Jika model SARIMA tidak memenuhi asumsi homoskedastisitas, maka perlu dibentuk satu model lagi yang bisa menjelaskan ragam data dengan memanfaatkan kuadrat sisaan dari model SARIMA, yaitu model Autoregressive Conditional Heteroskedasticity (ARCH) [2].

Pada penelitian-penelitian sebelunya, model SARIMA digunakan untuk data bulanan yang memiliki pola yang sama setiap tahun, dan model GARCH digunakan untuk data yang memiliki fluktuasi meningkat. Oleh karena itu, dalam penelitian ini digunakan model SARIMAARCH/GARCH untuk memodelkan data kunjungan wisatawan mancanegara melalui bandara Ngurah Rai Bali, karena data tersebut memiliki pola yang sama setiap bulan dengan fluktuasi meningkat setiap tahun.

\section{Landasan Teori}

Dalam melakukan analisis untuk data deret waktu, asumsi yang harus terpenuhi adalah data yang digunakan harus stasioner. Stasioneritas berarti bahwa tidak terdapat perubahan yang drastis pada data. Data deret waktu yang stasioner berfluktuasi disekitar rata-rata yang konstan dan ragam yang konstan.

Kestasioneran data dalam rata-rata dapat ditentukan dengan uji Augmented Dickey Fuller (ADF). Uji ADF dilakukan berdasarkan persamaan

$$
\nabla X_{t}=\phi_{0}+\phi_{1} X_{t-1}+Z_{t}
$$

dengan hipotesis uji:

- $H_{0}: \phi_{1}=0$ (data memuat akar unit atau data tidak stasioner),

- $H_{1}: \phi_{1}<0$ (data tidak memuat akar unit atau data stasioner),

dan statistik uji sebagai berikut

$$
A D F=\frac{\hat{\phi_{1}}}{\widehat{S E}\left(\hat{\phi}_{1}\right)}
$$


dan kriteria keputusan tolak $H_{0}$ jika nilai statistik uji ADF kurang dari nilai tabel $\mathrm{ADF}$.

Data yang tidak stasioner dalam rata-rata distasionerkan dengan melakukan differencing atau menghilangkan trend data. Operator difference lag 1 didefinisikan sebagai

$$
\nabla X_{t}=X_{t}-X_{t-1}=(1-B) X_{t}
$$

dengan B adalah operator backward shift, dan

$$
B X_{t}=X_{t-1}
$$

Proses differencing tidak terlalu baik digunakan untuk menstasioner-kan data yang tidak stasioner dalam ragam, sebab orde difference bisa tinggi, sehingga akan banyak data yang hilang. Oleh karena itu, data yang tidak stasioner dalam ragam dapat distasionerkan dengan transformasi stabilitas ragam.

Transformasi stabilitas ragam yang umum digunakan untuk data deret waktu adalah transformasi kuasa (power transformation), yang diperkenalkan dan dikembangkan oleh G.E.P. Box dan D.R.Cox sekitar tahun 1964. Persamaan transformasi kuasa (transformasi Box-Cox) adalah

$$
T\left(X_{t}\right)=X_{t}(\lambda)= \begin{cases}\frac{X_{t}^{\lambda}-1}{\lambda} & \lambda \neq 0 \\ \ln \left(X_{t}\right) & \lambda=0\end{cases}
$$

dengan $\lambda$ adalah parameter transformasi.

Selanjutnya, untuk mendeteksi kestasioneran data musiman pada periode musimannya dilakukan Uji seasonal unit root atau uji HEGY. Uji HEGY didasarkan pada persamaan berikut:

$$
\Theta^{*}(B)\left(1-B^{S}\right) X_{t}=\sum_{m=1}^{S} \rho_{m} X_{m, t}+Z_{t}
$$

dengan $\left\{Z_{t}\right\} \sim \operatorname{iid}\left(0, \sigma^{2}\right)$, dan $X_{m, t}=\zeta_{m}(B) X_{t}$, dan

$$
\zeta_{m}(B)=\left\{\begin{array}{ll}
\sum_{j=1}^{S} \cos \left(j \theta_{m}\right) B^{j} \quad m=1, m_{\text {genap }}, \pi \\
\sum_{j=1}^{S} \sin \left(j \theta_{m-1}\right) B^{j} \quad m=m_{\text {ganjil }}
\end{array} .\right.
$$

Pada frekuensi musiman 0 dan $\pi$, hipotesis uji yang digunakan adalah:

- $H_{0 m}: \rho_{m}=0$,

- $H_{1 m}: \rho_{m}<0$,

dengan $m=0, \pi$. Statistik uji yang digunakan adalah $t_{m}=\frac{\hat{\rho}_{m}}{\hat{\sigma}_{m}}$, dengan $\hat{\rho}_{m}$ adalah penduga untuk $\rho_{m}$ dan $\hat{\sigma}_{m}$ standart error dari $\hat{\rho}_{m}$.

Kriteria pengambilan keputusan, yaitu tolak $H_{0}$ jika nilai statistik t hitung kurang dari nilai tabel $t_{m}$, artinya tidak terdapat akar unit pada frekuensi yang diuji jika nilai statistik t hitung kurang dari nilai tabel $t_{m}$.

Pada frekuensi musiman selain 0 dan $\pi$, hipotesis uji yang digunakan adalah: 
- $H_{0 m}: \rho_{m}=\rho_{m+1}=0$

- $H_{1 m}: \rho_{m} \neq 0$ atau $\rho_{m+1} \neq 0$

Statistik uji yang digunakan adalah $F_{m, m+1}=\frac{1}{2}\left(t_{m}^{2}+t_{m+1}^{2}\right)$. Kriteria pengambilan keputusan, yaitu tolak $H_{0}$ jika nilai statistik $\mathrm{F}$ lebih dari nilai tabel $F_{m, m+1}$. Keputusan tolak $H_{0}$ berarti tidak terdapat akar unit pada frekuensi yang diuji.

Model deret waktu terdiri dari model Autoregressive (AR), model Moving Average (MA), dan model Autoregressive Moving Average (ARMA). Model Autoregressive (AR) pertama kali diperkenalkan oleh Yule (1926) dan kemudian dikembangkan oleh Walker (1931), sedangkan model Moving Average (MA) pertama kali digunakan oleh Slutsky (1937).

Definisi 2.1. [5] Misal $\left\{X_{t}\right\}$ adalah deret waktu stasioner, model Autoregressive dengan orde $p$ ditulis $A R(p)$ untuk $\left\{X_{t}\right\}$ didefinisikan sebagai

$$
X_{t}=\phi_{1} X_{t-1}+\cdots+\phi_{p} X_{t-p}+Z_{t}
$$

dimana $\phi_{i}$ adalah parameter $k e-i=1,2, \cdots, p$, dan $Z_{t} \sim W N\left(0, \sigma^{2}\right)$.

Definisi 2.2. [5] Misal $\left\{X_{t}\right\}$ adalah deret waktu yang stasioner, model Moving Average dengan orde $q$ ditulis $M A(q)$ untuk $\left\{X_{t}\right\}$ didefinisikan sebagai

$$
X_{t}=Z_{t}-\theta_{1} Z_{t-1}-\cdots-\theta_{q} Z_{t-q}
$$

$\theta_{i}$ adalah koefisien Moving Average dan $\left\{Z_{t}\right\} \sim W N\left(0, \sigma^{2}\right)$.

Definisi 2.3. [5] Misal $\left\{X_{t}\right\}$ adalah deret waktu yang stasioner, model Autoregressive Moving Average dengan orde $(p, q)$ ditulis $A R M A(p, q)$ untuk $\left\{X_{t}\right\}$ didefinisikan sebagai,

$$
X_{t}-\phi_{1} X_{t-1}-\cdots-\phi_{p} X_{t-p}=Z_{t}+\theta_{1} Z_{t-1}+\cdots+\theta_{q} Z_{t-q}
$$

dengan $\left\{Z_{t}\right\} \sim W N\left(0, \sigma^{2}\right)$.

Model AR, MA, dan ARMA yang telah dibahas hanya berlaku untuk data yang sudah stasioner. Untuk data yang belum stasioner, salah satu cara yang dapat menstasionerkan data adalah differencing.

Misal B adalah suatu operator sedemikian sehingga $B X_{t}=X_{t-1}$. Difference pertama, yaitu $\left(X_{t}-X_{t-1}\right)=(1-B) X_{t}$, dan difference ke- $d$ dinotasikan sebagai $(1-B)^{d} X_{t}$. Jika data deret waktu di modelkan dengan model $\operatorname{ARMA}(p, q)$ setelah didifference $d$ kali, maka model yang digunakan adalah model $\operatorname{ARIMA}(p, d, q)$ dengan $d$ menyatakan banyaknya difference yang dilakukan [5].

$\operatorname{ARIMA}(p, d, q)$ memiliki persamaan umum, yaitu

$$
\phi(B)(1-B)^{d} X_{t}=\theta(B) Z_{t}
$$

dengan $\phi(B)=1-\phi_{1} B-\phi_{2} B^{2}-\cdots-\phi_{p} B^{p}$ adalah polinomial dalam B berorde $p$ dan $\theta(B)=1+\theta_{1} B+\theta_{2} B^{2}+\cdots+\theta_{q} B^{q}$ adala polinomial dalam B berorde $q$.

Jika data deret waktu merupakan data musiman dengan periode waktu $S$, maka model Seasonal ARIMA (disingkat SARIMA) dapat diperoleh sebagai generalisasi dari model $\phi(B)(1-B)^{d} X_{t}=\theta(B) Z_{t}$. Misal $B^{S}$ menotasikan operator sedemikian sehingga $B^{S} X_{t}=X_{t-S}$, maka pembeda musiman dapat ditulis sebagai 
$\left(X_{t}-X_{t-s}\right)=\left(1-B^{S}\right) X_{t}$. Suatu model SARIMA dengan orde nonmusiman $(p, d, q)$ dan orde musiman $(P, D, Q)$ disingkat sebuah model $\operatorname{SARIMA}(p, d, q)(P, D, Q)_{S}$ dan didefinisikan sebagai

$$
\phi(B) \Phi\left(B^{S}\right)(1-B)^{d}\left(1-B^{S}\right)^{D} X_{t}=\theta(B) \Theta\left(B^{S}\right) Z_{t}
$$

dengan $\Phi, \Theta$ adalah polinomial pada $B^{S}$ dengan orde $P$ dan $Q$ [5].

Beberapa data deret waktu yang tidak stabil dihasilkan kuadrat sisaan pada waktu $t$ yang bergantung pada kuadrat sisaan pada waktu $t-1$. Kondisi tersebut mengakibatkan model deret waktu linier memiliki kecocokan yang rendah dengan data. Oleh karena itu, diperlukan model untuk mengatasi ketergantungan kuadrat sisaan pada model deret waktu linier. Model ini dikenal dengan model Autoregressive Conditional Heteroskedasticity (ARCH) dan General Autoregressive Conditional Heteroskedasticity (GARCH) [5].

Model $\operatorname{ARCH}(p)$ :

$$
\sigma_{t}^{2}=\alpha_{0}+\sum_{i=1}^{p} \alpha_{i} \varepsilon_{t-i}^{2}
$$

dengan $\alpha_{0}>0 ; 0<\alpha_{i}<1(i=1,2, \cdots, p)$ dan $\varepsilon_{t}^{2} \sim N\left(0, \sigma_{t}^{2}\right)$.

Model $\operatorname{GARCH}(p, q)$ :

$$
\sigma_{t}^{2}=\alpha_{0}+\sum_{i=1}^{p} \alpha_{i} \varepsilon_{t-i}^{2}+\sum_{j=1}^{q} \beta_{j} \sigma_{t-j}^{2}
$$

dengan $\alpha_{0}>0 ; \alpha_{i}, \beta_{j} \geq 0$ dan $\sum_{i=1}^{p} \sum_{j=1}^{q}\left(\alpha_{i}+\beta_{j}\right)<1$.

Adapun kriteria yang akan digunakan untuk menentukan model terbaik pada penelitian ini adalah sebagai berikut.

(1) Akaikes Information Criteria (AIC). Persamaan AIC dalam pemilihan model adalah

$$
A I C=-2 \ln \left(\hat{\sigma}^{2}\right)+2 k
$$

Model terbaik adalah model yang memiliki nilai AIC terkecil.

(2) Schwarz Criteria (SIC). Persamaan SIC dalam pemilihan model adalah

$$
S I C=-2 \ln \left(\hat{\sigma}^{2}\right)+k \ln (n)
$$

Model terbaik adalah model yang memiliki nilai SIC terkecil.

(3) Hannan and Quinn Criteria (HQ). Persamaan HQ dalam pemilihan model adalah

$$
H Q=\log \left(\hat{\sigma}^{2}\right)+\frac{2 k \ln (\ln (n))}{n}
$$

Model terbaik adalah model yang memiliki nilai HQ terkecil.

Setelah model terbaik diperoleh, maka akan dilakukan uji untuk asumsi sisaan model. Asumsi yang akan diuji terhadap model adalah asumsi autokorelasi sisaan, uji homoskedastisitas, dan uji normalitas sisaan. 
(1) Uji Autokorelasi Sisaan

Pengujian yang digunakan untuk mengetahui adanya autokorelasi pada sisaan model deret waktu adalah uji Ljung-Box. Hipotesis pengujian yang digunakan pada uji Ljung-Box adalah sebagai berikut[8],

- $H_{0}$ : tidak ada korelasi serial pada data,

- $H_{1}$ : terdapat korelasi serial pada data.

Statistik uji yang digunakan adalah

$$
Q=n(n+2) \sum_{k=1}^{h} \frac{\hat{\rho}_{k}}{n-k}
$$

dengan $n$ adalah ukuran sampel, $\hat{\rho}_{k}$ adalah autokorelasi sampel pada lag $k$, $h$ adalah banyaknya lag yang diuji. Pada taraf nyata $\alpha$, wilayah kritis pengujian ini adalah $Q>\chi_{h}^{2}$. Saat menggunakan uji Ljung-Box untuk menguji sisaan dari model ARIMA, derajat bebas perlu disesuaikan berdasarkan estimasi parameter. Sebagai contoh, untuk model $\operatorname{ARIMA}(p, 0, q)$, derajat bebas yang digunakan adalah $h-p-q$.

(2) Uji Homoskedastisitas

Uji homoskedastisitas digunakan dalam menguji keragaman dari sisaan. Salah satu statistik uji yang digunakan dalam uji tersebut adalah uji ARCHLM [4]. Misal suatu deret $\left\{Z_{t}\right\}$ adalah sisaan dari model deret waktu yang memenuhi persamaan $Z_{t}^{2}=b_{0}+b_{1} Z_{t-1}^{2}+\cdots+b_{k} Z_{t-k}^{2}+e_{t}$. Uji ARCH-LM didasarkan pada hipotesis berikut:

- $H_{0}: b_{i}=0(i=1, \cdots, k)$ (tidak terdapat ARCH dalam sisaan sampai lag ke- $k$ ),

- $H_{1}$ : ada $b_{i} \neq 0(i=1, \cdots, k)$ (terdapat efek ARCH dalam sisaan sampai lag ke- $k$ ),

dengan statistik uji:

$$
L M=n R^{2} .
$$

Kriteria pengambilan keputusan yang digunakan pada uji ARCH-LM adalah tolak hipotesis awal jika $L M>\chi_{k}^{2}$.

(3) Uji Normalitas Sisaan

Uji normalitas dilakukan untuk mengetahui kenormalan sebaran dari sisaan, dan digunakan uji Jarque-Bera[11]. Hipotesis uji yang digunakan adalah

- $H_{0}$ : data menyebar menurut sebaran normal,

- $H_{1}$ : data tidak menyebar menurut sebaran normal. Statistik uji yang digunakan adalah

$$
J B=\frac{n}{6}\left(S^{2}+\frac{(K-3)^{2}}{4}\right)
$$

$S$ adalah skewness atau ukuran ketidaksimetrisan dalam distribusi nilai dan $K$ adalah kurtosis atau indikator untuk menunjukkan derajat keruncingan. Kriteria pengambilan keputusan untuk uji Jarque-Bera adalah tolak $H_{0}$ pada taraf nyata $\alpha$ jika $J B \geq \chi_{2}^{2}$. 
Beberapa indikator yang umum digunakan untuk menentukan kecocokan model adalah sebagai berikut.

(1) Mean Absolute Percentage Error (MAPE). Secara matematis, MAPE dirumuskan sebagai berikut.

$$
M A P E=\frac{1}{m} \sum_{t=N-m+1}^{N} \frac{\left|X_{t}-\hat{X}_{t}\right|}{X_{t}},
$$

(2) Mean Absolute Deviation (MAD). MAD adalah perhitungan yang digunakan untuk menentukan rata-rata kesalahan mutlak.

$$
M A D=\frac{1}{m} \sum_{t=N-m+1}^{N}\left|X_{t}-\hat{X}_{t}\right|
$$

(3) Mean Square Error (MSE) Nilai MSE dapat dihitung dengan rumus sebagai berikut:

$$
M S E=\frac{1}{m} \sum_{t=N-m+1}^{N}\left(X_{t}-\hat{X}_{t}\right)^{2}
$$

\section{Pembahasan}

Data yang digunakan pada penelitian ini adalah data jumlah kunjungan wisatawan mancanegara per bulan ke Indonesia melalui bandara Ngurah Rai Bali pada bulan Januari 2008 sampai bulan Desember 2019

Pertama, akan diidentifikasi kestasioneran dari data jumlah kunjungan wisatawan mancanegara. Kestasioneran terhadap ragam ditentukan dengan melihat nilai $\lambda$ (parameter transformasi kuasa), dan kestasioneran data terhadap rata-rata ditentukan dengan melakukan uji ADF.

Data stasioner terhadap ragam jika memiliki nilai parameter transformasi kuasa atau $\lambda$ sama dengan 1 (satu). Jika $\lambda \neq 1$ maka data belum stasioner terhadap ragam, dan distasionerkan dengan transformasi sampai diperoleh $\lambda$ sama dengan 1 (satu).

Tabel 1. Nilai $\lambda$ data jumlah kunjungan wisatawan mancanegara

\begin{tabular}{|c|c|c|}
\hline Data jumlah kunjungan & Nilai $\lambda$ & Kesetaraan transformasi $T\left(X_{t}\right)=$ \\
\hline Data asli & 0.0 & $\ln \left(X_{t}\right)$ \\
\hline Data setelah transformasi 1 kali & -1.00 & $\frac{1}{X_{t}}$ \\
\hline Data setelah transformasi 2 kali & 1.00 & $X_{t}$ \\
\hline
\end{tabular}

Dari Tabel 1 terlihat bahwa nilai $\lambda$ untuk data bernilai 1 setelah 2 kali transformasi, artinya data yang stasioner terhadap ragam diperoleh setelah melakukan 2 kali transformasi. Selanjutnya, ketidakstasioneran data terhadap rata-rata dapat dilihat dari hasil uji ADF, dengan hipotesis awal data tidak stasioner terhadap rataan. 
Tabel 2. Hasil uji ADF data

\begin{tabular}{|c|c|c|c|c|}
\hline & \multicolumn{2}{|c|}{ Data sebelum difference } & \multicolumn{2}{c|}{ Data setelah difference } \\
\hline & t-statistik & Prob & t-statistik & Prob \\
\hline Statistik uji ADF & -0.471421 & 0.8920 & -8.829211 & 0.0000 \\
\hline Taraf nyata & -2.883408 & & -2.883408 & \\
\hline
\end{tabular}

Berdasarkan Tabel 2 terlihat bahwa statistik hitung ADF (-0.471421) lebih dari -2.883408. Diambil keputusan tidak tolak hipotesis awal dan dapat disimpulkan bahwa data setelah transformasi belum stasioner terhadap rata-rata. Oleh karena itu, dilakukan difference terhadap data setelah transformasi.

Statistik hitung ADF untuk data setelah transformasi dan setelah 1 (satu) kali difference adalah -8.829211 (kurang dari -2.883408). Diambil keputusan tolak hipotesis awal, dan dapat disimpulkan data jumlah kunjungan wisatawan mancanegara melalui bandara Ngurah Rai Bali stasioner setelah transformasi dan satu kali difference.

Selanjutnya, akan ditentukan kestasioneran musiman data setelah transformasi dan difference.

Tabel 3. Hasil seasonal unit root test

\begin{tabular}{|c|c|c|c|c|}
\hline & \multicolumn{2}{|c|}{$\begin{array}{l}\text { Data sebelum differ- } \\
\text { ence musiman }\end{array}$} & \multicolumn{2}{|c|}{$\begin{array}{l}\text { Data setelah difference } \\
\text { musiman }\end{array}$} \\
\hline & stats & tabel & stats & tabel \\
\hline Frekuensi 0 & -5.292449 & -2.81 & -5.052305 & -2.80 \\
\hline Frekuensi $2 \pi / 12$ dan $22 \pi / 12$ & 1.712890 & 8.15 & 16.09371 & 8.19 \\
\hline Frekuensi $4 \pi / 12$ dan $20 \pi / 12$ & 3.596588 & 8.15 & 22.14496 & 8.19 \\
\hline Frekuensi $6 \pi / 12$ dan $18 \pi / 12$ & 8.919994 & 8.15 & 19.46152 & 8.19 \\
\hline Frekuensi $8 \pi / 12$ dan $16 \pi / 12$ & 3.688048 & 8.15 & 9.885907 & 8.19 \\
\hline Frekuensi $10 \pi / 12$ dan $14 \pi / 12$ & 3.703687 & 8.15 & 15.63842 & 8.19 \\
\hline Frekuensi $\pi$ & -2.266672 & -1.92 & -4.190739 & -1.92 \\
\hline All seasonal frequencies & 4.782800 & 7.50 & 22.53764 & 7.54 \\
\hline All Frequencies & 7.540963 & 7.08 & 25.82214 & 7.12 \\
\hline
\end{tabular}

Berdasarkan Tabel 3, pada frekuensi 0 dan $\pi$, nilai statistik t kurang dari nilai tabel $\mathrm{t}$, pada frekuensi $\frac{6 \pi}{12}, \frac{18 \pi}{12}$ nilai statistik $\mathrm{F}$ lebih dari nilai tabel $\mathrm{F}$, artinya hanya pada frekuensi tersebut tidak terdapat akar unit atau data belum stasioner dalam periode musimannya. Setelah dilakukan difference musiman, diperoleh nilai statistik F untuk semua frekuensi lebih dari nilai tabel F, artinya data sudah stasioner setelah difference musiman.

Selanjutnya, dilakukan pendugaan untuk beberapa model, dan diperoleh lima model yang memiliki parameter signifikan. Parameter dikatakan signifikan jika 
memiliki nilai $p$-value kurang dari 0.05 .

Tabel 4. Nilai kriteria AIC, SIC dan HQ untuk model

\begin{tabular}{|c|c|c|c|}
\hline Model & AIC & SIC & HQ \\
\hline SARIMA $(1,1,0)(1,1,0)_{12}$ & -11.87064 & -11.78284 & -11.83496 \\
\hline SARIMA $(0,1,1)(1,1,0)_{12}$ & -11.93397 & -11.84617 & -11.89829 \\
\hline SARIMA $(1,1,0)(0,1,1)_{12}$ & -12.10886 & -12.02107 & -12.07318 \\
\hline SARIMA $(0,1,1)(0,1,1)_{12}$ & -12.15194 & -12.06414 & -12.11626 \\
\hline SARIMA $(1,1,1)(0,1,1)_{12}$ & -12.20575 & -12.09601 & -12.16116 \\
\hline
\end{tabular}

Dari Tabel 4, terlihat bahwa model $\operatorname{SARIMA}(1,1,1)(0,1,1)_{12}$ memiliki nilai AIC, SIC, dan HQ terkecil.

Tabel 5. Uji asumsi sisaan model

\begin{tabular}{|c|c|c|c|}
\hline Model & Uji autokorelasi & $\begin{array}{l}\text { Uji } \\
\text { heteros-kedastisitas }\end{array}$ & litas \\
\hline $\begin{array}{l}\operatorname{SARIMA}(1,1,0) \\
(1,1,0)_{12}\end{array}$ & $\begin{array}{l}\text { Terdapat kore- } \\
\text { lasi }\end{array}$ & $\begin{array}{l}\text { Terdapat } \\
\text { heteroskedastisitas }\end{array}$ & $\begin{array}{lr}\text { Sisaan } & \text { tidak } \\
\text { menyebar normal }\end{array}$ \\
\hline $\begin{array}{l}\operatorname{SARIMA}(0,1,1) \\
(1,1,0)_{12}\end{array}$ & $\begin{array}{l}\text { Tidak } \\
\text { berautokorelasi }\end{array}$ & $\begin{array}{l}\text { Tidak terdapat } \\
\text { heteroskedastisitas }\end{array}$ & $\begin{array}{lr}\text { Sisaan } & \text { tidak } \\
\text { menyebar normal }\end{array}$ \\
\hline $\begin{array}{l}\text { SARIMA }(1,1,0) \\
(0,1,1)_{12}\end{array}$ & $\begin{array}{l}\text { Tidak } \\
\text { berautokorelasi }\end{array}$ & $\begin{array}{l}\text { Terdapat } \\
\text { heteroskedastisitas }\end{array}$ & $\begin{array}{lr}\text { Sisaan } & \text { tidak } \\
\text { menyebar normal }\end{array}$ \\
\hline $\begin{array}{l}\operatorname{SARIMA}(0,1,1) \\
(0,1,1)_{12}\end{array}$ & $\begin{array}{l}\text { Tidak } \\
\text { berautokorelasi }\end{array}$ & $\begin{array}{l}\text { Terdapat } \\
\text { heteroskedastisitas }\end{array}$ & $\begin{array}{lr}\text { Sisaan } & \text { tidak } \\
\text { menyebar normal }\end{array}$ \\
\hline $\begin{array}{l}\text { SARIMA }(1,1,1) \\
(0,1,1)_{12}\end{array}$ & $\begin{array}{l}\text { Tidak } \\
\text { berautokorelasi }\end{array}$ & $\begin{array}{l}\text { Tidak terdapat } \\
\text { heteroskedastisitas }\end{array}$ & $\begin{array}{lr}\text { Sisaan } & \text { tidak } \\
\text { menyebar normal }\end{array}$ \\
\hline
\end{tabular}

Berdasarkan hasil uji asumsi sisaan model, sisaan model SARIMA $(1,1,1)$ $(0,1,1)_{12}$ tidak berautokorelasi dan tidak memuat efek heteroskedastisitas. Meskipun demikian, terdapat 3 model yang memuat efek heteroskedastisitas, yaitu model SARIMA $(1,1,0)(1,1,0)_{12}, \operatorname{SARIMA}(1,1,0)(0,1,1)_{12}$, dan $\operatorname{SARIMA}(0,1,1)$ $(0,1,1)_{12}$. Oleh karena itu, dipilih satu model dan diatasi efek heteroskedastisitas dengan mengestimasi model GARCH yang bersesuaian dengan model tersebut. Model yang dipilih adalah model $\operatorname{SARIMA}(0,1,1)(0,1,1)_{12}$, karena model tersebut memiliki nilai AIC, SIC, dan HQ terkecil. 
Model $\operatorname{SARIMA}(0,1,1)(0,1,1)_{12}$ dapat ditulis sebagai berikut.

$$
\begin{aligned}
\phi(B) \Phi(B)(1-B)^{d}\left(1-B^{S}\right)^{D} X_{t} & =\theta(B) \Theta\left(B^{S}\right) Z_{t} \\
(1-B)\left(1-B^{12}\right) X_{t} & =(1+\theta B)\left(1+\Theta B^{12}\right) Z_{t} \\
\left(1-B^{12}-B+B^{13}\right) X_{t} & =\left(1+\Theta B^{12}+\theta B+\theta \Theta B^{13}\right) Z_{t} \\
X_{t}-B^{12} X_{t}-B X_{t}+B^{13} X_{t} & =Z_{t}+\Theta B^{12} Z_{t}+\theta B Z_{t}+\theta \Theta B^{13} Z_{t} \\
X_{t}-X_{t-12}-X_{t-1}+X_{t-13} & =Z_{t}+\Theta Z_{t-12}+\theta Z_{t-1}+\theta \Theta Z_{t-13} \\
X_{t}=X_{t-1}+X_{t-12}-X_{t-13} & +Z_{t}+\theta Z_{t-1}+\Theta Z_{t-12}+\theta \Theta Z_{t-13}
\end{aligned}
$$

Selanjutnya, untuk mengatasi heteroskedastisitas digunakan model GARCH untuk memodelan ragam sisaan dari model SARIMA $(0,1,1)(0,1,1)_{12}$.

Tabel 6. Hasil estimasi model ARCH dengan SARIMA $(0,1,1)(0,1,1)_{12}$

\begin{tabular}{|l|l|l|l|l|l|}
\hline & ARCH(1) & GARCH $(1,1)$ & ARCH $(2)$ & GARCH $(2,1)$ & GARCH $(1,2)$ \\
\hline$\alpha_{0}$ & $1.16 \mathrm{E}-07$ & $3.63 \mathrm{E}-07$ & $3.91 \mathrm{E}-07$ & $3.58 \mathrm{E}-07$ & $3.60 \mathrm{E}-07$ \\
& $(0.0000)$ & $(0.7116)$ & $(0.0000)$ & $(0.7908)$ & $(0.7784)$ \\
\hline$\alpha_{1}$ & 0.171428 & 0.150000 & 0.150000 & 0.133333 & 0.133333 \\
& $(0.0000)$ & $(0.6642)$ & $(0.4676)$ & $(0.7858)$ & $(0.7700)$ \\
\hline$\alpha_{2}$ & & & 0.050000 & 0.044444 & \\
& & & $(0.6782)$ & $(0.9543)$ & \\
\hline$\beta_{1}$ & & 0.60000 & & 0.533333 & 0.533333 \\
& & $(0.5627)$ & & $(0.7490)$ & $(0.8957)$ \\
\hline$\beta_{2}$ & & & & & 0.044444 \\
& & & & & $(0.9891)$ \\
\hline AIC & -12.49859 & -11.67655 & -12.24053 & -11.57206 & -11.54743 \\
\hline SIC & -12.38895 & -11.54486 & -12.10885 & -11.41842 & -11.39379 \\
\hline HQ & -12.45410 & -11.62304 & -12.18702 & -11.50963 & -11.48500 \\
\hline
\end{tabular}

Berdasarkan tabel 6 model ARCH(1) memiliki AIC, SIC dan HQ terkecil, maka model ragam terbaik untuk model SARIMA $(1,1,0)(0,1,1)_{12}$ adalah $\mathrm{ARCH}(1)$. Berdasarkan persamaan $(3.6)$, misal $X_{t}=\frac{1}{\ln \left(Y_{t}\right)}$, dan $\left\{Y_{t}\right\}$ adalah data kunjungan wisatawan mancanegara ke Indonesia maka model $\operatorname{SARIMA}(1,1,0)(0,1,1)_{12}$ dapat ditulis sebagai berikut

$X_{t}=X_{t-1}+X_{t-12}-X_{t-13}+Z_{t}-0.682682 Z_{t-1}-0.940076 Z_{t-12}+0.641766 Z_{t-13}$

Adapun model ARCH(1) dapat ditulis sebagai berikut

$$
\begin{aligned}
\sigma_{t}^{2} & =\alpha_{0}+\alpha_{1} \varepsilon_{t-1}^{2} \\
\sigma_{t}^{2} & =1.16 E-07+0.171428 \varepsilon_{t-1}^{2}
\end{aligned}
$$

Berikut tabel yang menunjukkan perbandingan kecocokan model SARIMA dan model SARIMA-ARCH dengan data. 
Tabel 7. Tabel MAPE, MAD dan MSE model

\begin{tabular}{|c|c|c|c|}
\hline Model & MAPE & MAD & MSE \\
\hline SARIMA $(1,1,1)(0,1,1)_{12}$ & 3.4847207 & 0.002702786 & $8.90873 \mathrm{E}-06$ \\
\hline SARIMA $(0,1,1)(0,1,1)_{12}$-ARCH $(1)$ & 0.6542427 & 0.000507869 & $4.51488 \mathrm{E}-07$ \\
\hline
\end{tabular}

Berdasarkan Tabel 7, terlihat bahwa model SARIMA $(0,1,1)(0,1,1)_{12^{-}} \operatorname{ARCH}(1)$ memiliki nilai MAPE, MAD, dan MSE terkecil. Oleh karena itu, model $\operatorname{SARIMA}(0,1,1)(0,1,1)_{12}-\mathrm{ARCH}(1)$ memiliki kecocokan yang lebih baik dibandingkan model SARIMA $(1,1,1)(0,1,1)_{12}$. Hasil ini juga mengonfirmasi bahwa model SARIMA-ARCH mampu mengatasi masalah heteroskedastisitas, dan memberikan model yang lebih baik daripada model SARIMA.

\section{Kesimpulan}

Berdasarkan hasil eksplorasi, data jumlah kunjungan wisatawan mancanegara melalui bandara Ngurah Rai Bali belum stasioner dalam ragam. Oleh karena itu, digunakan transformasi Box-Cox untuk menstasionerkan data. Data hasil transformasi tersebut akan digunakan untuk mengestimasi model terbaik.

Berdasarkan hasil penelitian yang diperoleh, dapat disimpulkan bahwa model SARIMA-ARCH lebih baik dari model SARIMA dalam melakukan pendugaan untuk data penelitian ini. Model yang memiliki kemampuan pendugaan terbaik untuk data adalah model SARIMA $(0,1,1)(0,1,1)_{12}-\mathrm{ARCH}(1)$, dengan persamaan:

$X_{t}=X_{t-1}+X_{t-12}-X_{t-13}+Z_{t}-0.682682 Z_{t-1}-0.940076 Z_{t-12}+0.641766 Z_{t-13}$

dengan persamaan ragam

$\sigma_{t}^{2}=1.16 \times 10^{-7}+0.171428 \varepsilon_{t-1}^{2}$.

dengan $X_{t}=\frac{1}{\ln \left(Y_{t}\right)},\left\{Y_{t}\right\}$ adalah data kunjungan wisatawan mancanegara ke

Indonesia, $\sigma_{t}^{2}$ adalah ragam pada waktu $t$, dan $\varepsilon_{t-1}$ adalah galat dari model $\operatorname{SARIMA}(0,1,1)(0,1,1)_{12}$ pada waktu $t-1$.

\section{Daftar Pustaka}

[1] Badan Pusat Statistik. 2021. Jumlah Kunjungan Wisatawan Mancanegara perbulan ke Indonesia Menurut Pintu Masuk. www.bps.go.id. Diakses pada 20 Februari 2021.

[2] Box, G.E., Jenkins, G.M., dan Reinsel,G.C. 1994. Time Series Analysis Forecasting and Control Third Edition. New Jersey: Prentice-Hall Internasional,Inc.

[3] Brockwell, P.J., Davis, R.A. 2001. Introduction to Time Series and Forecasting Second Edition. Colorado: Springer.

[4] Catani, P.S, Ahlgren,N.J.C. 2017. Combined Lagrange multiplier test for ARCH in vector autoregressive models. Econometrics and Statistics.(1): $62-84$.

[5] Chatfield, C. 2000. Time-Series Forecasting. Boca Raton: Chapman\& Hall/CRC. 
[6] Hannan, E., Quinn,B. 1979. The Determination of the Order of an Autoregression. Journal of the Royal Statistical Society. Series B (Methodological), 41(2): 190 - 195.

[7] Fadhilla, D.R., Devianto, D., Maiyastri. 2015. Time Series Modeling for Risk of Stock Price with Value at Risk Computation. Applied Mathematical Sciences, 9(56): $2779-2787$

[8] Ljung, G., Box, G. 1978. On a Measure of Lac of Fit in Time Series Models. Biometrika, 65(2): 297-303. doi:10.23072335207.

[9] Meng, X., Changeli, H. 2012. Testing Seasonal Unit Roots in Data at Any Frequency, an HEGY Approach. Swedia: Dalarna University.

[10] Ningsih, P., Maiyastri, Asdi, Y. 2019. Peramalan Jumlah Kedatangan Wisatawan Mancanegara ke Sematera Barat melalui Bandara Internasional Minangkabau dengan Model SARIMA. Jurnal Matematika Unand 8(2): 128 - 134.

[11] Thadewald,T., Buning,H. 2004. Jarque-Bera test and its Competitors for Testing Normality: A Power Comparison. Discussionsbeitrage, No.2004/9. 